\title{
レーザ照射によるゼオライトモルタル表面のガラス化に関する研究 GLASS LAYER FORMATION ON ZEOLITE MORTOR BY LASER IRRADIATION
}

\author{
永井香織*，市原 英樹*，ウィグナラージャ シバクマラン** \\ Kaori NAGAI, Hideki ICHIHARA and Wignarajah SIVAKUMARAN
}

\begin{abstract}
Although laser is widely used for cutting, welding and surface treating metals, application of the laser for processing inorganic architectural materials is quite rare. In this study, the feasibility of using laser energy to form glass layers on mortar panels with zeolite aggregate was assessed. The effects of mix composition and laser irradiation parameters on the characteristics of the glass layer and on the flexural strength of zeolite mortar panels were investigated.

It was found that the optimum mix composition and laser irradiation parameters for obtaining panels with high flexural strength and stable glass layers were as follows: zeolite particle size $=0.6$ to $1.2 \mathrm{~mm}, \mathrm{~W} /(\mathrm{C}+\mathrm{Z})=25$ to $30 \%$, cementzeolite mass ratio $=1: 2$ to $1: 3$, Laser power $=1 \mathrm{~kW}$, beam diameter $=200 \mathrm{~mm}$ and work travel speed $=750 \mathrm{~mm} / \mathrm{min}$.
\end{abstract}

Keywords: Laser, Zeolite mortar, Glass layer, Surface treatment レーザ, ゼオライトモルタル, ガラス層, 表面処理

1.はじめに

わが国における天然ゼオライト1は，30年前から主に農・畜産・水産業 の分野に利用されている。この背景には，日本における天然ゼオライトの 資源が豊富であることやゼオライトには, 独立気泡をもつ, 比重が小さい, 吸放湿性をもつおよび陽イオン交換性などの特性 2)を有していることがあ げられる。

建設分野における天然ゼオライトの利用方法は, 図-1に示すように比重 が小さいことを利用して，軽量骨材に用いる方法3) および陽イオン交換性 によるコンクリート用混和材料に用いる方法4 (5) の研究開発および抗菌 シーリング材6)や吸放湿性を有する内壁用パネルの開発》.87 が行われてき た．内装材として利用するためには，パネル表面にクロスや塗料などの仕 上材が必要である。このように，内装材としてのゼオライトモルタルに関 する研究はあるが，レーザ照射によって表面にガラス層を形成する研究は 見当たらない.

本研究は, ゼオライトモルタル表面にレーザを照射し, 表面にガラス層 を形成9)して，吸放湿性を損なわずに美観性を付与した内装壁材用夕イル としてゼオライトモルタルパネルを作成することを目的としている。レー ザは，瞬間加熱・瞬間冷却の特性があり，シリカ質を含む無機材料の表面 をレーザ照射することで, 表面のシリカ質を溶融し表層のみにガラスを形 成することができる，この方法を採用することにより，パネル全体を加熱

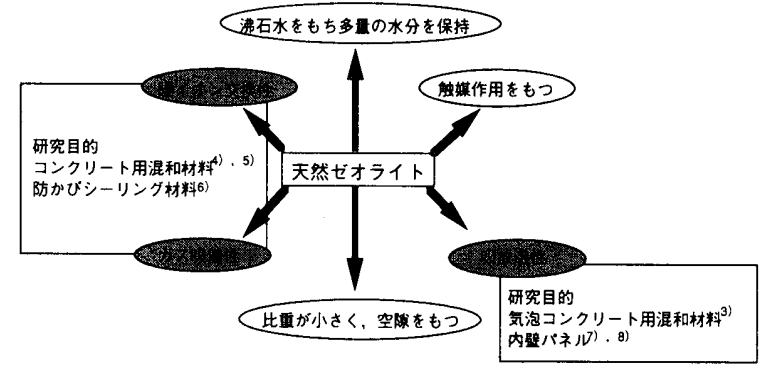

図一 1 天然ゼオライトの性質と建築分野に関連する既往の研究

することなく，表層のみをガラス化することが可能である．本論文は以下 の3項目について検討したものである.

1）実験に用いるレーザ発振機およびレンズの種類の検討

2) ゼオライトモルタルパネルの調合と曲げ強さの検討

3）レーザ照射したゼオライトモルタルパネル表面のガラス層および曲げ強 さの検討

\section{2. 実験に使用するレーザ発振機およびレンズの検討}

\section{1 レーザ発振機の検討}

ゼオライトモルタルの表面にレーザ照射をおこなうと表面が瞬時に高温 になり表層のみゼオライトに含まれる $\mathrm{SiO}_{2}$ が溶融しガラス化する.この現
*大成建設侏技術センター 研究員

** 大成建設㮫技術センター 主任研究員・工博
Research Engineer, Taisei Corporation

Senior Research Engineer, Taisei Corporation, Dr. Eng. 
象は,レーザ発振機およびレンズの種類によって表面のガラス化状態およ び効率が異なる. 現在, 実用化されているレーザ発振機は, 表-1に示す波 長が $0.193 \mu \mathrm{m} \sim 10.6 \mu \mathrm{m}$ のものがある. 実験に使用するレーザ発振機の 選定に当たって, 市販されている各種レーザ発振機の出力, エネルギー変 換効率, レーザ光の波長と材料表面での吸取率の関係, 表面のガラス化に 必要なエネルギーなどについて検討した.エキシマレーザ・アレキサンド ライドレーザは，最大出力が小さいため，ガラス層の形成ができない， Nd.YAGレーザは, ガラス層を形成できるが, エネルギー変換効率が $\mathrm{CO}_{2}$ レーザより悪い. $\mathrm{CO}_{2}$ レーザは, $10.6 \mu \mathrm{m}$ の波長を有し, 最大出力, エネ ルギー変換効率の点から本実験に適している. そこで, 本実験では, $\mathrm{CO}_{2}$ レーザ発振機（T社製 $1.2 \mathrm{kWCO}$ レーザ）を用いることとした。

2.2 レーザのレンズの検討

効率のよいレーザ照射条件の設定をおこなうために, 4種類のレンズを 用いて最適なガラス化が得られるレンズについて検討した。

\section{2 .1 試験体}

使用したモルタルは, 普通ポルトランドセメントと, 粒径 $0.6 \sim 1.2$ (mm) の天然ゼオライト (Clinoptilolite : $\left.\mathrm{Na}_{6}\left[\mathrm{Al}_{6} \mathrm{Si}_{30} \mathrm{O}_{72}\right] \cdot 24 \mathrm{H}_{2} \mathrm{O}\right)$ 14) を用 いて, セメント: ゼオライト $=1: 2$ (質量比), 水/ (セメント+ゼオライ ト) $=20 \sim 40 \%$ とした，試験体寸法は，300×300×12（mm）とし，モル タルを型枠に打設し振動プレスで成型後, 蒸気養生 $\left(80^{\circ} \mathrm{C} 3\right.$ 時間)をおこ なった。この蒸気養生条件は,パネルの脱型可能な条件として設定したも のである、なお混和剤を使用した場合，モルタルにレーザ照射すると，形 成したガラス層が炭化や着色など, 別の影響を及ほすために, 本実験では 使用しないこととした。

2.2.2 使用したレンズおよびレーザ照射条件

実験に使用したレンズの特徴およびレーザ照射条件を表-2に示す.使用 したレンズは, オシレートミラー, シリンドリカルレンズ, セグメントミ ラー, 凹凸レンズの4種類である. 実験は, 各レンズを用いて試験体に対 してレーザ照射条件を変化させ,表面に形成したガラス層の爆裂状況およ びガラス層の厚さを目視・顕微鏡で確認した.レーザ照射条件は, 各レン ズを用いてガラス化できる範囲で行った。

\section{3 結果および考察}

レーザ照射エネルギーとガラス量および爆裂状況を図-2に示す。セグメ ントミラーは, 低エネルギーで厚いガラス層が得られるが, ガラス層の爆 裂も多くなっている.凹凸レンズは, 照射エネルギーが大きくなるに伴い ガラス量および懪裂も多くなっている.オシレートミラーは, これらのレ ンズに比し，高エネルギーでガラス層を形成している．このように, ガラ スの量および爆裂状況は,照射エネルギーとレンズの種類によって異なっ ている、これは、レンズによってエネルギー密度が異なるために, 溶融さ れる過程で, ガラス層の形成状態が若干異なると考えられる. 本研究で は,化粧性の観点から爆裂しないでガラス層を形成することを目的として いる，セグメントミラーは，低エネルギーで厚いガラス層が得られてい る.このレンズは, 表-2のように光の成形が小さく光の密度が高くなるた め, 照射面が高温となりガラス化量が多くなる.しかし, 光の密度が高い と, 溶融する過程で表面が急激に高温になるため，母材のゼオライトモル 夕ルに含まれる水分が表面に到達し, ガラス層が爆裂し, 表面のガラス層 が平滑になりにくい. 本実験では，その目的からガラスの爆裂が多くなる レンズの使用は不適切であるので,図に示すように爆裂せずにガラス層が 形成できる適正ライン前後に拉いて最もエネルギーの少ない凹凸レンズを 採用することとした。
表一1 レーザ発振機の種類

\begin{tabular}{|c|c|c|c|c|c|}
\hline \multicolumn{2}{|c|}{ レーザの種類 } & 波長 $(\mu \mathrm{m})$ & $\begin{array}{c}\text { 最大出力 } \\
(\mathrm{kW})\end{array}$ & $\begin{array}{c}\text { 工视ギー効率 } \\
(\%)\end{array}$ & 主な応用 \\
\hline \multirow{3}{*}{ エキシママレーH゙ } & $\mathrm{ArF}$ & 0.19 & \multirow{3}{*}{0.2} & \multirow{3}{*}{2} & \multirow{3}{*}{$\begin{array}{l}\text { 光化学, プロセス } \\
\text { 超伝導分野 }\end{array}$} \\
\hline & $\mathrm{KrF}$ & 0.25 & & & \\
\hline & $\mathrm{XeCl}$ & 0.31 & & & \\
\hline \multicolumn{2}{|c|}{ アレキサンドラ价ーサ } & $0.7-0.8$ & 0.15 & 2 & $\begin{array}{l}\text { 金属, セラミック } \\
\text { の孔開け }\end{array}$ \\
\hline \multicolumn{2}{|c|}{ Nd:YAGV-H" } & 1.06 & 2 & 2 & $\begin{array}{l}\text { ICなどの精密加工 } \\
\text { マーキング, 医療 }\end{array}$ \\
\hline \multicolumn{2}{|c|}{$\mathrm{CO}_{2} \mathrm{l}-+$} & 10.6 & 50 & 15 & $\begin{array}{l}\text { 金属, 非金属の } \\
\text { 加工! 医療 }\end{array}$ \\
\hline
\end{tabular}

表一2 実験に使用したレンズの種類および照射条件

\begin{tabular}{|c|c|c|c|c|c|}
\hline \multicolumn{2}{|c|}{ レンスの種類 } & 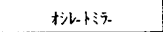 & ションドリカルンス & t方・氺 & 凹凸レ， \\
\hline \multicolumn{6}{|c|}{ エネルギー密度の } \\
\hline & 特對 & $\begin{array}{l}\text { 照射幅も大きく，均 } \\
\text { 一に照射出来るが， } \\
\text { 装䁂が大規模 }\end{array}$ & $\begin{array}{l}\text { 焦点外し距蜼を変化 } \\
\text { させても } \\
\text { 照射幅はあまり変化 } \\
\text { しない } \\
\end{array}$ & $\begin{array}{l}\text { 均一に照射出来る } \\
\text { が, 光つ成形加小 } \\
\text { いく，照射径を変化 } \\
\text { せて照射幅はあま } \\
\text { り変化しない } \\
\end{array}$ & 照射径を変化させる \\
\hline \multirow{3}{*}{ 照射 } & 出力 $(\mathrm{kW})$ & $0.3-1.5$ & $0.78-1.17$ & $0.3-1.00$ & $0.5-1.2$ \\
\hline & $\begin{array}{c}\text { 焦点外し距神 } \\
(\mathrm{mm})\end{array}$ & $50-450$ & $200-400$ & $300-500$ & $200-300$ \\
\hline & $\begin{array}{l}\text { 照射速度 } \\
(\mathrm{mm} / \mathrm{min} .)\end{array}$ & $0.10-1.50$ & $0.30-0.60$ & $0.44-2.80$ & $0.50-1.50$ \\
\hline \multicolumn{2}{|c|}{$\begin{array}{l}\text { 照射エネルギ-- } \\
\left(\mathrm{k} \cdot \mathrm{wh} / \mathrm{m}^{2}\right)\end{array}$} & $1.7-2.5$ & $1.3-1.7$ & $1.2-2.5$ & $0.7-2.2$ \\
\hline
\end{tabular}

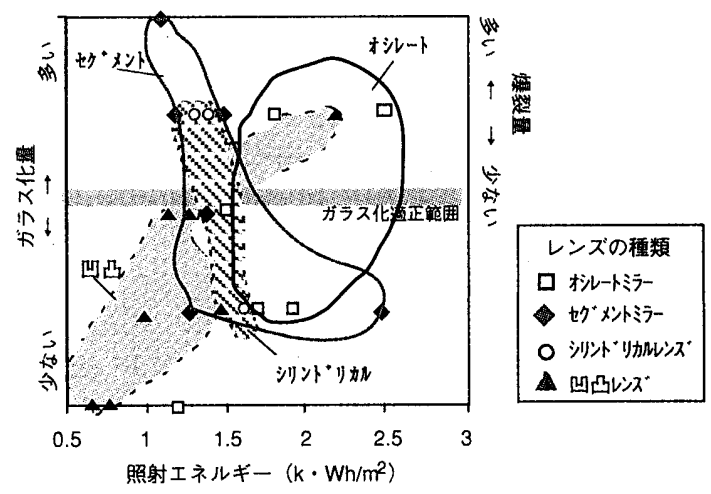

図一2 レーザ照射エネルギーとガラス層の厚さ・爆裂状況

3. ゼオライトモルタルパネルの調合と曲げ強さ

ゼオライトは，独立気泡をもち，吸放湿特性を有する骨材であるために， 練り混ぜ時に多く吸水し，打設しにくい. また，ゼオライトが $\mathrm{SiO}_{2}$ を多く 含んでいるために, ゼオライトの量が増加すればよりガラス化しやすいが， ゼオライトの量を增やすと強度が低下寸る。そこで，これらのことを考慮 し, しかも内装壁用パネルとしての所要強度が得られる調合を求めるため に実験をおこなった。

\section{1 実験方法}

\subsection{1 試験体の種類および作製}

使用材料は, 普通ポルトランドセメントおよび絶乾状態の天然ゼオライ ト（Clinoptilolite）を用いた。調合は，表-3に示すように質量比でセメント： ゼオライト (以後これを $\mathrm{C}: \mathrm{Z}$ と表す.) $=1: 1 \sim 1: 3$ の 5 水準とし, $\mathrm{C}: \mathrm{Z}=1$ ： 2 については, ゼオライトの粒径を $0 \sim 0.6,0.6 \sim 1.2,1.2 \sim 3.0(\mathrm{~mm})$ の 3 水 準について実験した。水量はW/ $(C+Z)$ で示し, 20〜40\%とし，各調合で 打設可能な範囲とした，打設可能な範囲は, 練り混ぜができること, 振動 プレス成形ができることの条件を判断基準とした．練り混ぜは，アイリッ 七型ミキサーで粉体練り 30 秒, 水を添加後 1 分練り混ぜた。モルタルは, 
振動プレス機を用いて打設し，その後 $80^{\circ} \mathrm{C} 3$ 時間蒸気養生を行った。蒸気 盖生後, 脱型し材令 28 日まで温度 $20^{\circ} \mathrm{C}$ 湿度 $60 \%$ の室内で保存した。試験体 寸法は, $300 \times 300 \times 15(\mathrm{~mm})$ とした.

\subsection{2 曲げ試験方法}

パネルの曲げ試験は, JIS A 5209(陶磁器質夕イル)に準じ, 曲げスパン $150 \mathrm{~mm}$ ，試験体の幅 $8 \mathrm{~cm}$ として試験した，曲汗試験は，材齢 28 日でおこ なった。パネルの曲げ試験結果は,(1)式によって幅 $1 \mathrm{~cm}$ 当たりの曲げ破壊 荷重（以後「曲げ強さ」と呼ぶ）を求めた。

$$
\mathrm{P}=\mathrm{F} / \mathrm{b} \times 1 / 90 \quad \cdots . . . . . .-(1) \text { 式 }
$$

ここに, $\mathrm{P}$ ：幅 $1 \mathrm{~cm}$ 当たりの曲げ破壊荷重 $(\mathrm{N} / \mathrm{cm})$

$$
\begin{aligned}
& \mathrm{F} \text { : 破壊荷重 }(\mathrm{N}) \\
& \mathrm{b}: \text { パネルの幅 }(\mathrm{cm}) \\
& \mathrm{l}: \text { スパン }(\mathrm{mm})
\end{aligned}
$$

試験は，同一条件で3個おこない，3個の平均值で示した。 パネルの曲げ 試験に用いた供試体は， $300 \times 300 \times 15(\mathrm{~mm})$ のパネルから, $80 \times 180 \times$ $15(\mathrm{~mm})$ の試験片を切り出したものを用いた。

\section{2 結果および考察}

\section{$3.2 .1 \mathrm{~W} /(\mathrm{C}+\mathrm{Z})$ と曲汗強さの関保}

パネルの $\mathrm{W} /(\mathrm{C}+\mathrm{Z})$ と曲げ強さの関係を図 -3 に示す。曲げ強さは，3個 の平均値を示したものであり，これらの変動保数は，9.10２7.6(\%)の範 囲である。本パネルの使用部位を内装壁用としており，パネルの目標とす る曲げ強さを定めるにあたり，JIS A 5209 (陶磁器質タイル) の内装壁用の 基準である $12(\mathrm{~N} / \mathrm{cm})$ としたが，この值では脱型時に角が欠ける場合があっ たので，この值の約 3 倍の $35(\mathrm{~N} / \mathrm{cm})$ を目標曲げ強さとした，全体的にW/ $(\mathrm{C}+\mathrm{Z})$ が大きくなるほど，曲げ強さが大きくなっている，これは，一般に 言われている傾向と異なった結果を示している. そこで, 粒径0.6-1.2mm お よび 1.2-3.0mmの試験体の密度と曲げ強さとの関係を図-4に示した，W/ $(\mathrm{C}+\mathrm{Z})$ が小さいものは，密度が小さくなっている。これは，W/(C+Z)が小 さいと密実に充填されていないためで，その結果，曲げ強さが小さくなっ たものと考えられる．本実験から，ゼオライトモルタルの成形可能なW/ (C+Z)は，七メントとゼオライトの質量比によって若干異なり，今回行っ た実験の $\mathrm{W} /(\mathrm{C}+Z)$ は粒径 $0 ０ .6$ では $25 \sim 33 \% ， 0.6 \sim 1.2$ では $20 \sim 40 \%$, $1.2 \sim 3.0$ では $20 \sim 33 \%$ となった. 特に, 粒径が $0-0.6 \mathrm{~mm}$ のものは, 打設可 能な水量の範囲が狭まっている，水量の範囲と成形性を考虑すると，粒径 0.6〜1.2mmが使用しやすいことが確認できた。

\section{$3.2 .2 \mathrm{C}: \mathrm{Z}$ と曲げ強さの関保}

粒径別に成形可能な W/(C+Z)の範囲は，25３0\%が最も良かったＷ/ $(C+Z) 25 \%$ と 30\%の場合の C:Z と曲げ強さとの関係を図 -5 に示す。いづ

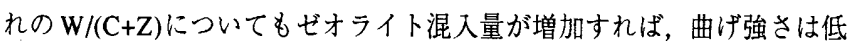
下している.W/(C+Z)25\%の場合，粒径 1.2〜3.0 $\mathrm{mm}$ の曲沙さは目標值 をこえているが，その他の粒径ではほとんど目標値に達していない，W/ (C+Z)30\%の場合は, 25\%と同様にゼオライト混入量が大きくなるほど, 曲 げ強さは小さくなっている。しかし，25\%に比べると目標值を越える調合 は多くなっている。

\section{4. ゼオライトモルタルパネルのガラス化と曲げ強さ}

ぜオライトモルタルパネルの調合とガラス化状況, ガラス化の有無によ るパネルの曲沪強さを検討した。

\section{1 実験方法}

\begin{tabular}{|c|c|c|c|c|c|c|c|c|}
\hline \multicolumn{4}{|c|}{ 用合 } & \multirow[b]{2}{*}{ 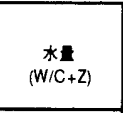 } & \multicolumn{3}{|c|}{ レーザ条件 } & \multirow[b]{2}{*}{ 泍定項目 } \\
\hline C:Z & 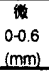 & $\begin{array}{c}1 \text { 㽢 } \\
0.6-1.2 \\
\text { (mm) }\end{array}$ & $\begin{array}{c}\text { 柤 } \\
1.2-3.0 \\
(\mathrm{~mm})\end{array}$ & & $\begin{array}{l}\text { 出力 } \\
(\mathrm{kW})\end{array}$ & $\begin{array}{l}\text { DFs } \\
(\mathrm{mm})\end{array}$ & $\begin{array}{l}\text { 連度 } \\
\text { (mmmmint }\end{array}$ & \\
\hline $1: 1$ & - & 0 & $\overline{-}$ & \multirow{5}{*}{ 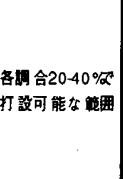 } & \multirow{3}{*}{1.00} & \multirow{3}{*}{200} & \multirow{3}{*}{$\begin{array}{c}500 \\
750 \\
1000\end{array}$} & \multirow{3}{*}{ 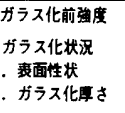 } \\
\hline $1: 1.5$ & - & 0 & - & & & & & \\
\hline $1: 2$ & 0 & 0 & 0 & & & & & \\
\hline $1: 2.5$ & $\overline{-}$ & 0 & - & & \multirow{2}{*}{1.00} & \multirow{2}{*}{200} & \multirow{2}{*}{750} & \multirow{2}{*}{ ガラス化權の强度 } \\
\hline $1: 3$ & - & 0 & - & & & & & \\
\hline
\end{tabular}

\subsection{1 試験体の種類および作成}

前項3.1.1 と同様とする.
表一 3 試験条件

(a) 粒径 0-0.6mm

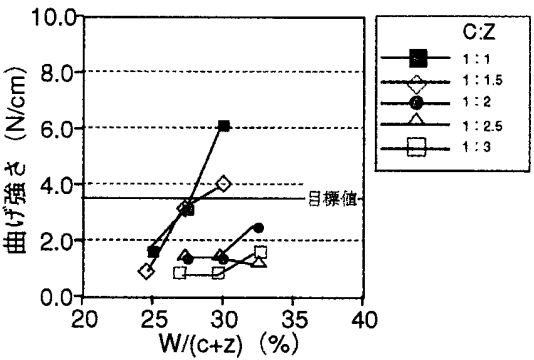

(b)粒径0.6-1.2mm

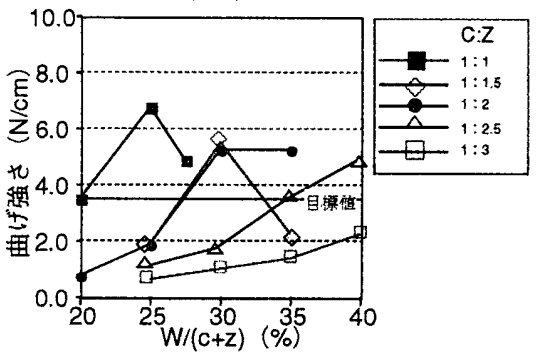

(c)粒径 1.2-3.0mm

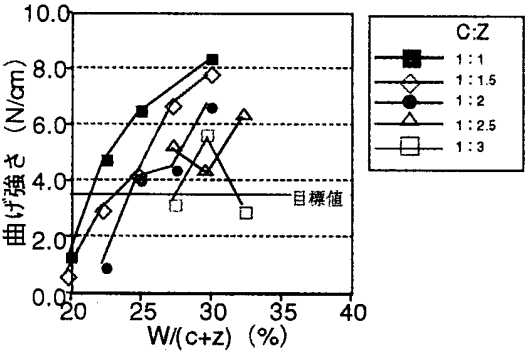

図一 3 粒徍別 $\mathrm{W} /(\mathrm{C}+Z)$ と曲げ強さの関係

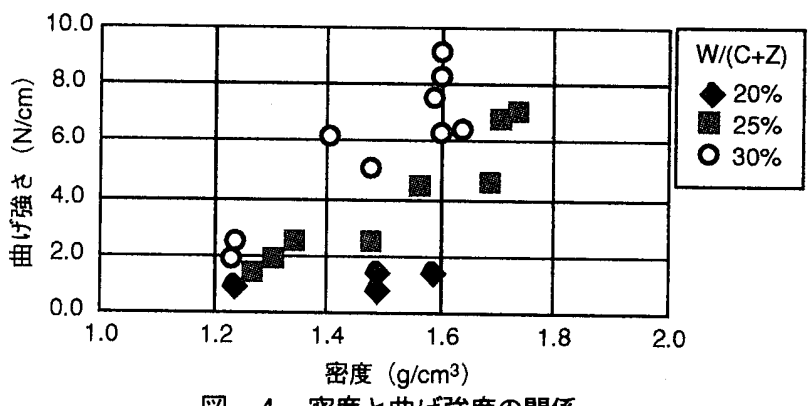

図一 4 密度と曲げ強度の関係

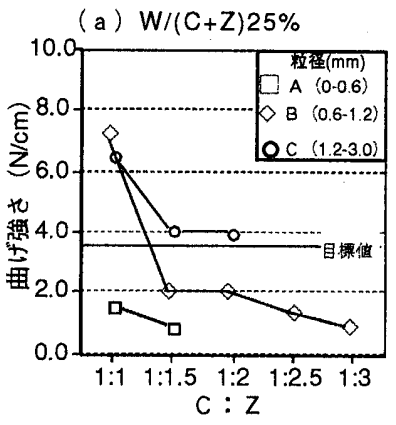

(b) $W /(C+Z) 30 \%$

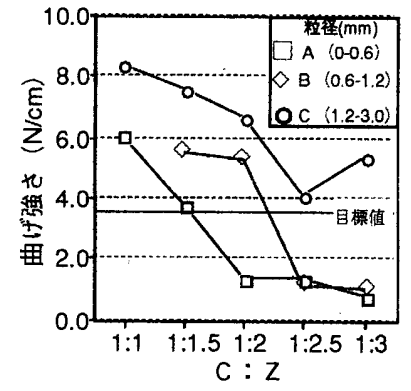

図- $5 \quad W /(C+Z)$ 別 $C: Z$ と曲げ強さの関係 


\subsection{2レーザ照射条件}

レーザは, $1.2 \mathrm{kWCO}$ レーザ発振機および凹凸レンズを使用した. 照射条 件は，表-3に示すように出力 $1.0 \mathrm{~kW}$ ，照射径 $200(\mathrm{~mm})$ を一定とし，照射 速度を $500,750,1000(\mathrm{~mm} / \mathrm{min}$.) の3水準とした。

4.1.3 測定項目

剆定項目は，表-3に示す各調合別のガラス化状況(爆裂の有無)，表面性 状，ガラス化後の曲け強さとした，ガラス化状況は，目視観察，表面性状 は，電子顕微鏡により観察した. ガラス化厚さは，断面を顕微鏡で測定し た。曲げ試験は，前項と同様におこなった。ただし，ガラス層を引張側に して載荷した。

\section{2 実験結果}

4.2.1 ガラスの顕微鏡観察

セメント:ゼオライト $=1: 2$ の粒径 $0.6 \sim 1.2 \mathrm{~mm}$ と粒径 $1.2 \sim 3.0 \mathrm{~mm}$ の場合 の表面の顕微鏡写真を写真 -1 に示す：レーザ照射条件はいづれも出力 $1 \mathrm{~kW}$ ，照射径 $200 \mathrm{~mm}$ ，照射速度 $750 \mathrm{~mm} / \mathrm{min}$.の場合である．粒径の小さい ものは, 表面が全体的に溶けてガラス化しているが, 粒径の大きいものは, 溶けにくくゼオライトの上部や周囲の一部のみ溶融している。この結果， 均質なガラス層を得るためには粒径が小さい方が有効である，

4.2.2 照射速度とガラス厚の関係

出力 $1 \mathrm{~kW}$, 照射径 $200 \mathrm{~mm}$ の場合のレーザ照射速度とガラス厚の関係を 図-6に示す.この図の横軸は速度が遅いほどエネルギーが高いことを示し ている. 粒径 $1.2 \sim 3.0 \mathrm{~mm}$ については, レーザ照射速度 $750,1000 \mathrm{~mm} / \mathrm{min}$. ではガラス層がほとんど確認できなかったので,ガラス厚を示していない，

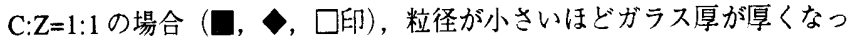
ている.また, ガラス厚は, レーザ照射速度が $750 \mathrm{~mm} / \mathrm{min}$.の時がどの粒径 においても最も厚くなっている。これは，レーザ照射速度が早いとガラス 化するための表面の熱エネルギーが小さいため，ガラス化しにくくなる． 一方レーザ照射速度が遅くなると，表面に対する熱エネルギーが大きくな り，ガラス層は形成されるが爆裂によってガラス層が剥離するため,ガラ
ス厚が薄くなる，照射速度 $750 \mathrm{~mm} / \mathrm{min}$. で, 粒径0.6-1.2mm の場合の C: $Z$ 別 (•，，、印）を見ると，ゼオライト混入量が多いほどガラス厚は厚く なっている.これは，ゼオライトが多いほど， $\mathrm{SiO}_{2}$ 含有量が多く，ガラス 化しやすくなったためである. 以上のように，レーザ照射によってゼオラ イトモルタル表面に形成したガラス層の厚さは，照射速度が遅いほど（照 射エネルギーが高いほど）厚くなるが爆裂しやすくなる，また，ゼオライ トの粒径, 混入量からみると, 粒径が細かいほど, またゼオライトの

写真-1 粒径別表面顕微鏡写真
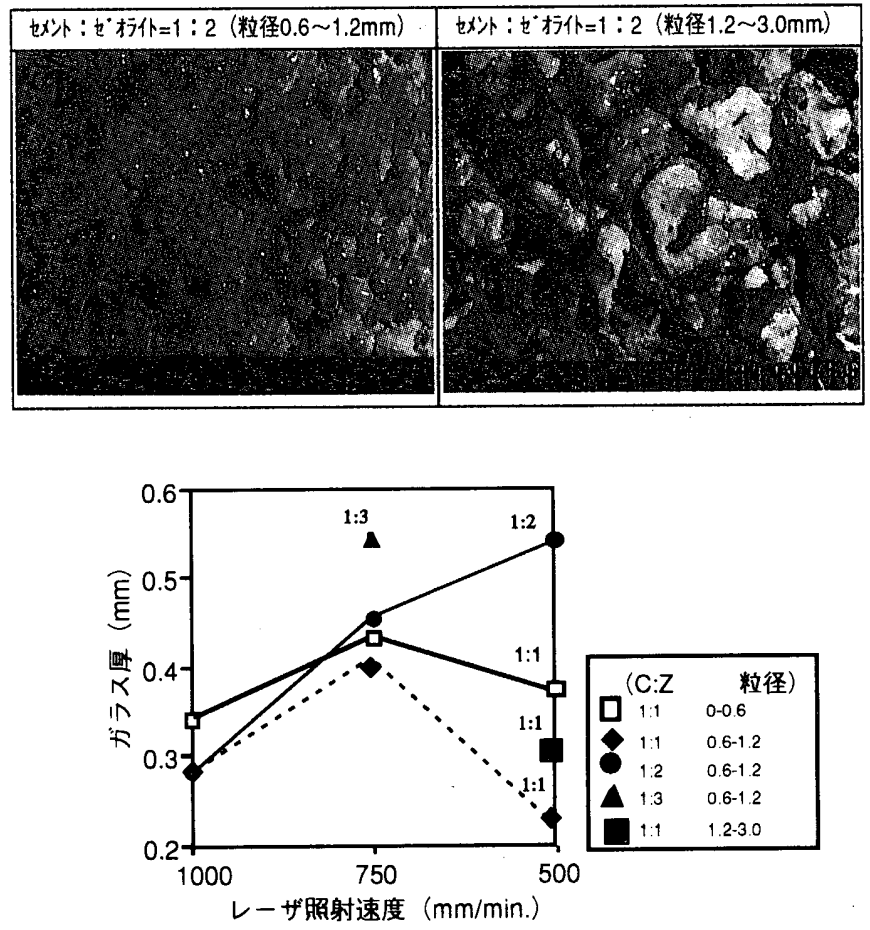

図一 6 レーザ照射条件別ガラス化厚さ

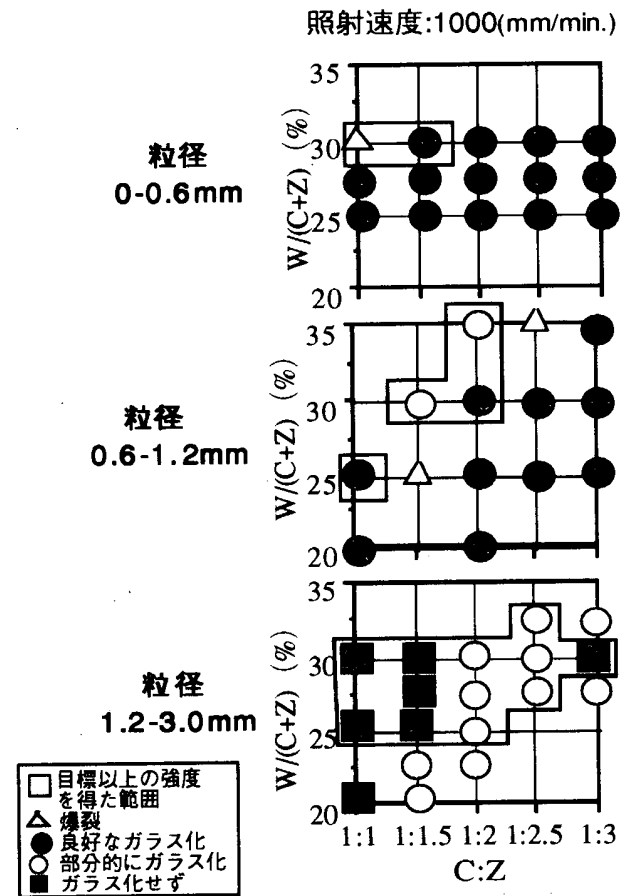

照射速度:750(mm/min.)
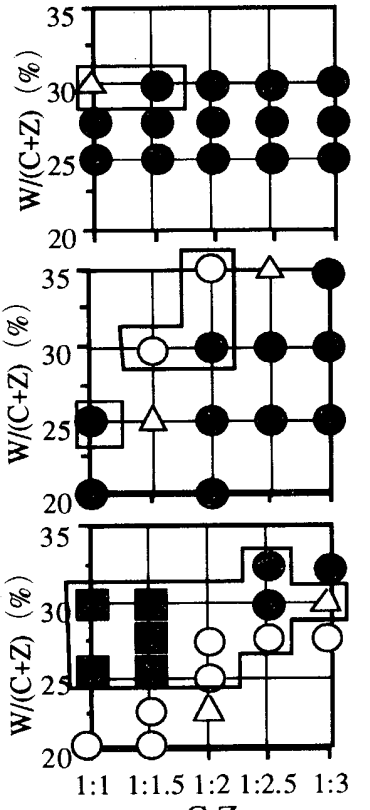

$C: Z$
照射速度: $500(\mathrm{~mm} / \mathrm{min}$ )
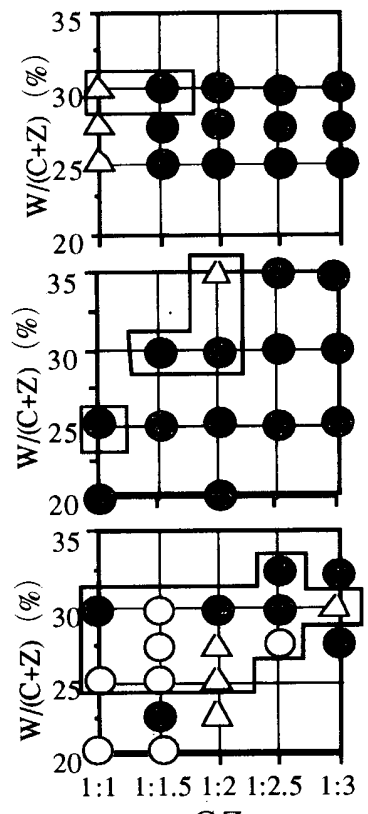

C:Z

図ー7 ゼオライトモルタルの調合別ガラス化状況 
混入量が多いほど, 厚いガラス層が形成される.このような 結果から，照射速度は $750 \mathrm{~mm} / \mathrm{min}$., ゼオライトの粒径は0.6$1.2 \mathrm{~mm}, \mathrm{C}: \mathrm{Z}$ は $1: 2 \sim 1: 3$ がガラス化に有効な条件となる。 4.2.3 調合・照射速度とガラス化状態

図-7は, C: Z, W/ $(\mathrm{C}+\mathrm{Z})$ とガラス化状態との関係をゼオ ライトの粒径別およびレーザの照射速度別に示したものであ る.図中に示す口部分は, 目標曲げ強さを満たした調合を示 している、粒径が細かいほど溶融しやすいために，良好なガ ラス層が得られているが, 目標とする曲げ強さが得られる調 合の範囲は狭い.ガラス化の状態と曲げ強さを照合すると, 粒径が $0 \sim 0.6 \mathrm{~mm}$ の場合, W/ (C+Z) 30\%の C: $\mathrm{Z}=1: 1.5$ のみ 目標値を満たしているが,パネル表面に微細なひび割れが発

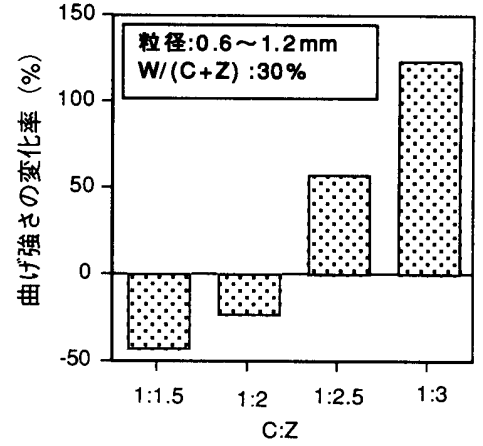

図ー8 C:Zと曲げ強さ変化率

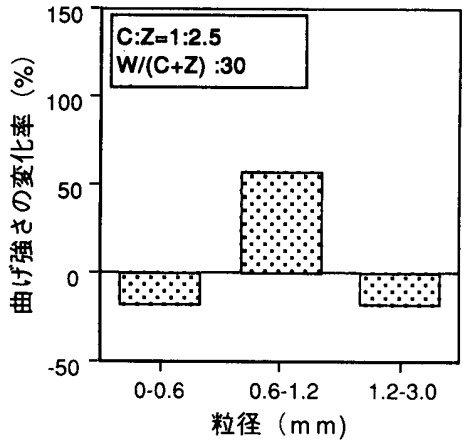

図ー9＼cjkstart粒径と曲げ強さ変化率 生していた，粒径0.6〜1.2mmは，W/ $(\mathrm{C}+\mathrm{Z}) 30 \%$ で C: $\mathrm{Z}=1$ :

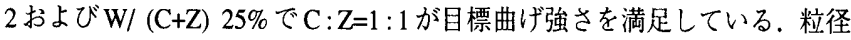
1.2 3.0mmは, 目標の曲げ強さを満たしている範囲は多いが, ガラス層が 爆裂したり，部分的なガラス層となり，均質なガラス層が得にくい． 4.2.4 ガラス化後のパネルの曲げ強度

図 -8および図-9にレーザ照射前に対する照射後の曲げ強さ変化率を示 す。曲げ強さの変化率は (2) 式によって求めた。

曲げ強さの変化率 $(\%)=\frac{(\text { 照射後の曲げ強さ }) \text {-(照射前の曲げ強さ })}{\text { 照射前の曲け強さ }} \times 100---$ - (2) 式

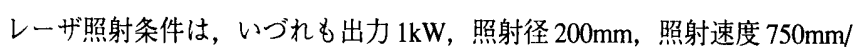
$\min$.の場合を示す。

図-8 を見ると，W/ $(\mathrm{C}+\mathrm{Z}) 30 \%$ の場合，C: $\mathrm{Z}=1: 1.5$ および $1: 2$ はレーザ照 射前の曲げ強さの方が大きいが, $\mathrm{C}: \mathrm{Z}=1: 2.5$ 以上ではレーザ照射後の方が 大きくなっている。これはゼオライト混入量が多くなるとガラス化の厚さ が厚くなったためである. 図-9を見ると, 粒径0.6〜 1.2mmのみで曲げ強さ が増加している.この理由は, 粒径が小さいとガラス層が形成されるが, 母 体との界面で浮きや剥がれが見られたため，照射後の強さが小さくなる. また，粒径が大きいと表面のガラス化量が少ないために曲げ強さの向上に はならなかったものと推測できる. 粒径0.6 1.2mmは, ガラス化および曲 げ強さが満足できる值を示した。

\section{5. むすび}

本研究は，吸放湿性を有するゼオライトを用いたパネルにレーザ照射す ることにより表層のみをガラス化させ, 美観性を付与した内装用パネルの 開発を目的として，ゼオライトモルタルパネルの調合およびレーザ照射条 件を変えて実験を行った，その結果を以下に要約する。

1) ゼオライトモルタルの表面にガラス層を形成するには $\mathrm{CO}_{2}$ レーザ発振機 が適している，また，使用するレンズは凹凸レンズが適している，

2) ゼオライトモルタルパネルの曲げ強さは, ゼオライトの粒径が大きいほ ど大きくなる。

3）レーザ照射によりゼオライトモルタル表面に形成したガラス層は, ゼオ ライトの粒径が小さいほど均質なものが得られるが，母材との界面で剥離 しやすい.

4）レーザの照射エネルギーを大きくするとガラス厚は増加するが, 爆裂し やすく表面が平滑にならない。

5）レーザ照射後のパネルの曲げ強さは，W/ $(\mathrm{C}+\mathrm{Z})=30 \%$, 粒径 0.6-1.2mm,
セメント : ゼオライト $=1: 2.5$ 以上では, 表面のガラス化により照射前の強 度より大きくなる。

6）良好な曲げ強さおよびガラス層が得られる調合条件は, ゼオライトの粒 径 $0.6 \sim 1.2 \mathrm{~mm}$, セメント: ゼオライト $=1: 2 \sim 1: 3 て ゙, W /(C+Z)$ は $25 \sim 30 \%$ の範囲である。

7）前項の調合条件で均質なガラス層が得られるレーザ照射条件は, 出力 $1 \mathrm{~kW}$ ，DFs $200 \mathrm{~mm}$ ，照射速度 $750 \mathrm{~mm} / \mathrm{min}$. である。

今後は, ガラス化したゼオライトモルタルの吸放湿性について報告した い.

\section{[謝辞]}

本研究をおこなうに当たり，ご助言を頂いた松井勇教授 (日本大学)，実 験にご協力頂いた五十嵐一美氏並びに粕谷正広氏 (奥多摩工業)に心から 感謝の意を示します。

\section{【参考文献】}

1）野田修司：農・水・畜産業に㧍けるゼ㧍仆の活用，化学と工業，第 38 巻第 11 号, pp.109-110, 1985

2）湊秀雄：ゼオラ仆の応用資源とその利用，七5シックスNo.10，pp.17-33，1975.12

3）荒井良延他, ゼオラ仆系調湿パ礼に関する研究開発その3, 日本建築学会大会学 術講演梗概集, pp.825-826, 1991.9

4）荒井良延他，ビ才ラ仆系調湿パ礼に関する研究開発その 4 , 日本建筑学会大会学 術講演梗概集, pp.947-948, 1992.8

5）荒井良延他，ゼオラ仆系調湿パ礼に関する研究開発その5, 日本建築学会大会学 術講演梗概集, pp.1229-1230, 1993.9

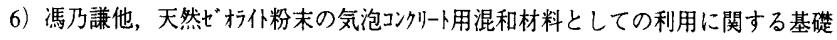
研究，七メ技術年報 No. 38，pp.142-145，昭和 59 年

7）林治郎他，天然ゼオラ仆を用いた謂湿材料の開発に関する研究，日本建築学会大 会学術講演梗概集, pp.185-186, 1992.8

8）寒河江昭夫他，ゼオ仆系調湿パ祃に関する研究開発その1〜2, 日本建䈎学会大 会学術講演梗概集, pp.1095-1098, 1990.10

9）ウイグナラージャシバクマラン他，Laser Surface Treatment of Natural Stone and Cement Composite，大成建設技術研究所所報 24

10）馮乃謙他，コ㚈ートの強度增進材としてのビオラ仆の有効性に関する研究，日本建 築学会構造系論文報告集第 388 号, pp.9-16, 昭和 63 年, 6 月

11）王宗玉他，天然ゼ杇作を用いたコ夘ートの強度特性に関する研究，セイト・コンクリート 論文集 No.44，pp.210-215，1990

12）王宗玉他，天然ビ杇作のアルカリ骨材反応揤制機構に関する研究，ヒメ怆ンク 归論文集 No.45, pp.572-575, 1991

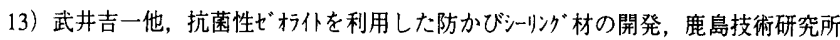
年報第 43 号, 1995.12

14）日本環境衛生センター，石綿・ぜオライトのすべて，環境庁大気保全局企画課 監修, pp.481-482, 昭和 62 年 12 月 10 日出版

(2000年11月 10 日原稿受理, 2001 年 5 月 7 日採用決定 